\title{
A Mall Intercept Survey on Religion and Worldview in the Cape Flats of Cape Town, South Africa
}

\section{Thomas J. Farrar, Khanyisane A. Falake, Adriel Mebaley, Mandisi D. Moya, and Ivor I. Rudolph Correspondence: farrart@cput.ac.za}

\begin{abstract}
This study analyzes worldviews and religious beliefs and practices in the Cape Flats area of Cape Town, South Africa, using a mall intercept survey of $n=513$ visitors to five shopping centers. Variables considered included demographic characteristics, measures of religiosity and religious pluralism, participation in religious activities, and supernaturalism (both related and unrelated to a traditional Christian-Abrahamic worldview). The majority (69.4\%) of respondents identifies as Christian, though denominational affiliation is very diverse. The other two prevalent religious affiliations are the African Traditional Religion (16.4\%) and Islam (11.7\%). Only $1.6 \%$ of the respondents selfidentified as non-religious, a smaller percentage than has been found in research on Cape Town as a whole or South Africa nationally. The degree of self-reported religiosity, participation in religious activities, and belief in supernatural phenomena are all high. Associations between demographic characteristics and religion and worldview variables are analyzed in detail.
\end{abstract}

Keywords: mall intercept, religion, worldview, survey, Cape Flats, South Africa 
Farrar, Falake, Mebaley, Moya \& Rudolph

\section{Background}

Inasmuch as this study concerns a survey on religion and worldview, a good place to begin is with working definitions of these two terms. While religion is a concept sometimes considered 'resistant to definition' (Adriaanse 1999), many attempts at a definition have been made. Durkheim famously defined religious phenomena as consisting of beliefs and practices - 'obligatory beliefs, connected with clearly defined practices which are related to given objects of those beliefs' (Durkheim [1899] 2011:93). Neville (2018:19) offers a heuristic, anthropologically oriented definition of religion as 'human engagement with ultimacy'. This is a good working definition for this empirical study, which explores the extent to which certain theoretical and normative notions of religion are reflected in 'lived religion' or 'religion from below', that is, religion 'as expressed and experienced in the lives of individuals' (McGuire 2008:3; Sremac \& Ganzevoort 2017:5) in a particular local context.

The concept of worldview is important in a contemporary religious discourse. Numerous researchers have offered definitions of the term 'worldview'. For Barna (2003:6), a worldview is a 'framework' enabling an 'understanding of how life works and the best options to pursue'. While some conceptualize worldview in terms of a set of propositions that one espouses (Barna 2003; Keys 2004; Lanier 2010), others argue that worldview is an ontological reality that goes beyond a set of propositions. A worldview is sometimes expressed in terms of a series of existential questions that it addresses (Wright 1992; Sire 2004; Collins 2006).

The past several decades have witnessed downward trends in the religious affiliation and participation in most Western countries. The secularizing trend in the West has generally been accompanied by a decline in belief in the transcendent and supernatural (Barna 2003; Houtman \& Aupers 2007). Such changes may be related to $20^{\text {th }}$-century developments such as postmodernism and, in a specifically Christian context, demythologization. Postmodernism has caused traditional worldviews to become relativized and localized (Harris 2004). Demythologization is a Christian hermeneutical program championed by Bultmann ([1941] 1984), who has strongly influenced contemporary Western Christian worldviews. Demythologization involves the reinterpretation of mythical biblical language deemed incompatible with a scientific worldview (e.g. resurrection, demon-possession) in existentialist terms. 
Pertaining to Christianity in particular, this 'precipitous decline in the West', combined with 'phenomenal growth in the non-West' has 'transformed Christianity into a non-Western religion' (Hanciles 2008:96). Sub-Saharan Africa has been one of the areas of this phenomenal growth (Pew Forum 2010:19). Within sub-Saharan Africa, few cities are as cosmopolitan and multicultural as Cape Town with its diverse blend of African, European, and Asian cultural traditions. Given that the structure of worldview is culturally dependent (Keys 2004:18), the religious landscape of Cape Town represents a fascinating field of inquiry.

The purpose of this study is to characterize religion and worldview within the Cape Flats community of Cape Town. Although not formally demarcated, the Cape Flats area features prominently in a local geographical vernacular. A low-lying plain characterized by wind-blown sand, the Cape Flats area is Cape Town's 'least hospitable area...on which the majority of the city's poorer residents live' (Wilkinson 2000:198). Residential areas consist largely of public housing estates known as 'townships' and of informal settlements, populated predominantly by isiXhosa-speaking 'Black Africans' and people belonging to an ethnically heterogeneous group of brown people known colloquially as 'Coloureds' (Amoateng 1997) ${ }^{1}$. The Cape Flats area represents an interesting population for religious studies not only due to its rich cultural diversity but also due to its resilience against the backdrop of a painful history of oppression. The role of religiosity in collective healing from racebased marginalization has also been documented in other contexts (eg. Johnson 2016).

There has been a dearth of demographic research on religion and worldview in South Africa, relative to Western countries. Statistics South Africa dropped religious affiliation from its census questionnaire prior to the 2011 census because ' $[t]$ he question on religion was low on the list of priorities as informed by the users of census data' (Statistics South Africa 2011a). Statistics South Africa's annual General Household Survey revived the religious affiliation question in 2013 (together with one frequency-ofreligious-observance question) but dropped it again in 2016 (Statistics South

1 These labels are placed in inverted commas throughout the essay to acknowledge that classifying people according to 'race' or 'population group', while still unavoidable in demographic research due to the lingering socioeconomic legacy of apartheid, is problematic and risks perpetuating ethnic stereotypes. 
Africa 2016; cf. also 2017; Schoeman 2017). The All Media and Products Survey, a now-defunct annual South African market research survey, asked respondents which religion, if any, they belong to, and for those who selected 'Christian', they asked their denomination (South African Audience Research Foundation 2014:65). Affiliation alone in any case provides little insight into worldview and religious practices. A detailed demographic research on religion is useful, not only for social scientists, but also for faith communities, who can thereby assess their success in engaging with and transforming the society around them (Theron \& Lotter 2009).

In the Cape Town Metropolitan Municipality subsample of the 2015 General Household Survey, the most popular responses to the religious affiliation question were Christian (82.3\%), Muslim (8.0\%), Traditional African Religion (3.8\%), and Nothing in Particular (3.1\%) (authors' own analysis of Statistics South Africa data). The objective of this study is to accurately profile the religion and worldview of the Cape Flats population according to several variables, namely: Religious affiliation and practices, religiosity and pluralism, and supernaturalism. A further objective is to investigate associations between these variables as well as their demographic predictors. The underlying hypothesis is that the Cape Flats population is highly religious and dominated by a worldview that accommodates supernaturalism.

\section{Methods}

\section{Survey instrument}

A standard battery of demographic items (sex, age, race, home language, nationality, and education level) was used, borrowed mainly from the South African 2011 census questionnaire (Statistics South Africa 2011b). A screening question was used to exclude respondents below the age of 15 . For religious and denominational affiliation questions, categories were taken from the South African 2001 census results (City of Cape Town 2015). Questions about frequency of attendance at religious services, prayer, and reading of a sacred text were based on the International Social Survey Program questionnaire on religion (ISSP Research Group 2012). 
Numerous researchers have proposed measures of religiosity and spirituality, as well as related attributes such as fundamentalism and pluralism ${ }^{2}$. The questionnaire used in this study included two items on religiosity and spirituality based on the ISSP Research Group (2012:12): 'I consider myself to be a religious person' and 'I consider myself to be a spiritual person'. Four questions about religious pluralism were taken from Vermeer and Van der Ven (2004:45), including 'The only way to true salvation is given to mankind in my religion' and 'Religions are all equal; they are all directed at the same truth'.

Instruments designed to measure one's idea of God are also abundant ${ }^{3}$. Our questionnaire included one item from Zinnbauer, Pargament, Cole, Rye, Butter, Belavich, Hipp, Scott and Kadar (1997:564) which categorizes belief in God as theistic, deistic, pantheistic, agnostic, or atheistic. Measurement scales designed to measure belief in the supernatural (or specific aspects thereof) can likewise be found in numerous sources ${ }^{4}$. The questionnaire included nine items (listed below in Figure 2), adapted from Jong, Bluemke and Halberstadt (2013) that collectively measure what we term Christian-Abrahamic supernaturalism. The items were designed to discern nuanced differences in belief within a majority-Christian population and therefore reflect a degree of religious bias, which is not, however, intended to imply the normativity of Christianity. The '-Abrahamic' suffix indicates that most of these items are also applicable to the other Abrahamic religions, Islam and Judaism.

These were followed by five questions about other supernatural phenomena (eg. 'People who practice witchcraft can have magical powers'; 'It is possible to communicate with the dead'; 'The ancestors provide guidance in the lives of those who are still living'). These were drawn or adapted from the

2 Cf. Smith, Hout \& Marsden (1972-2012); Batson (1976); Clark (1991); Altemeyer \& Hunsberger (1992); Steensland, Park, Regnerus, Robinson, Wilcox \& Woodberry (2000); Houtman \& Mascini (2002); King \& Crowther (2004); Vermeer \& Van der Ven (2004); ISSP Research Group (2012); Pennycook, Cheyne, Seli, Koehler \& Fugelsang (2012).

3 Cf. Berrenberg (1987); Zinnbauer, Pargament, Cole, Rye, Butter, Belavich, Hipp, Scott \& Kadar (1997); Houtman \& Mascini (2002); De Graaf \& Te Grotenhuis (2008).

4 Cf. Osarchuk \& Tatz (1973); Burkett \& White (1974); Wilcox, Linzey \& Jelen (1991); Wilson \& Huff (2001); Norenzayan \& Hansen (2006); Baker (2008); De Graaf \& Te Grotenhuis (2008); Jong, Bluemke \& Halberstadt (2013). 
Farrar, Falake, Mebaley, Moya \& Rudolph

ISSP Research Group (2012:6) and Pennycook, Cheyne, Seli, Koehler and Fugelsang (2012:340).

With the exception of the age question, the questionnaire consisted entirely of closed-choice questions and thus yielded quantitative, categorical data. The response rating scales for opinion or belief items consisted of a fivepoint Likert scale with a midpoint. The questions eliciting an opinion or orientation used a 'Strongly Agree/Agree/No Opinion/Disagree/Strongly Disagree' scale. Questions involving the veracity of a proposition used a 'Definitely True/Probably True/Can't Choose/Probably False/Definitely False' scale. Response categories were designed, based on the recommendations of Garland (1991), Preston and Colman (2000), and specifically Weijters, Cabooter and Schillewaert (2010).

\section{Sampling methodology}

\section{Mall intercept method}

Although less well-known in social science research than household, telephone, and internet surveys, the mall intercept method is a widely used survey technique in consumer research (Sudman 1980:423). The underlying principle of this method is that a relatively large proportion of the population of a residential area could be encountered with non-zero probability at the local mall. This allows one to draw a quasi-random sample from this population. The main advantage of the mall intercept method is its cost-effectiveness (low travel and telecommunication expenses). Besides cost, the security risks of household surveys in high-crime areas, and the logistical difficulties with limiting a telephone or internet survey to a local population, made the mall intercept method an ideal option for the present study.

This method does have its disadvantages. There are challenges relating to shoppers' time constraints and lack of privacy, which may result in high non-response rates (Bush \& Parasuraman 1984). Moreover, it is difficult to obtain a representative sample because of the lack of a sampling frame and because different members of the population have different probabilities of being at the mall. Indeed, for some people (eg. shut-ins) this probability is zero. For these reasons, Sudman (1980:424) cautions that 'shopping center samples will continue to have somewhat larger biases than careful household area or telephone probability samples'. However, various methods of reducing selec- 
tion bias in mall intercept surveys have been proposed (Sudman 1980; Blair 1983; Bush \& Hair 1985; Nowell \& Stanley 1991). Sudman (1980:426) states that 'careful sampling necessitates counting customers as they pass a specified point'. In this study, enumerators, after finishing a questionnaire, approached every fourth individual that passed a specified line on the floor inside the entrance. This eliminated any personal judgment in participant selection. Sudman further notes that the characteristics of people visiting shopping centers vary due to the time of the year, the day of a week or month, the time of day, weather conditions, etc. In this study, the data collection took place both on weekdays and Saturdays, spread over a two-month period (March to May). However, the timetabling was not completely random, because enumerator availability was constrained by university lecture timetables. At shopping centers with multiple entrances, enumerators rotated randomly between entrances. The management at five shopping centers in the Cape Flats was approached and they agreed to allow the survey to take place on their premises. These were Airport Shopping Centre (Belhar), Westgate Mall (Mitchells Plain), Gugulethu Square (Gugulethu), Philippi Plaza (Philippi), and Charlesville Mall (between Valhalla Park and Gugulethu).

\section{Sample size}

Most of our measurements were taken on an ordinal or nominal Likert scale with more than two response choices. Thompson (1987) provides a method for selecting a sample size to ensure that the resulting multinomial proportions can be estimated within a specified margin of error with a specified confidence level. Using R statistical software (R Core Team 2018), Thompson's method was used to calculate the smallest sample size necessary to achieve a given margin of error with $95 \%$ confidence (cf. Table 1 ).

\begin{tabular}{|l|l|}
\hline Margin of error $(\boldsymbol{d})$ & Sample size $(\boldsymbol{n})$ \\
\hline $0.01=1 \%$ & 12,736 \\
\hline $0.02=2 \%$ & 3,184 \\
\hline $0.03=3 \%$ & 1,416 \\
\hline $0.04=4 \%$ & 796 \\
\hline $0.05=5 \%$ & 510 \\
\hline
\end{tabular}

Table 1: Margin of error vs. sample size for simultaneous multinomial proportion estimation: Using a $d$ value of 0.05 , a minimum sample size of $n=510$ was calculated.

The sample size actually achieved was $\mathrm{n}=513$. 


\section{Non-response}

Non-response occurs when a customer is selected and approached, but they decline to participate. Hornik and Ellis (1988) warn that the mall intercept method is subject to high non-response rates and suggest remedial techniques. Despite implementing these recommendations, this study faced a very high non-response rate of $72.9 \%$. This is clearly a significant source of error in the statistical estimates. However, it should be noted that respondents were not informed about the topic of the survey until after agreeing to participate - it is therefore unlikely that non-response decisions were determined by attitudes towards religion. More likely, the high non-response rate was driven by customers being preoccupied or hurried, or misinterpreting the enumerator as a salesperson and hence dismissing their request summarily. Thus, there is no reason to suspect that the non-response rate has seriously biased statistical estimates pertaining to religious affiliation, beliefs, or practices.

Enumerators in this study were trained to refuse those who offered to participate without being selected, to avoid the problem of volunteer bias (Hornik \& Ellis 1988), which is an opposite but equally serious problem to non-response bias in survey research.

\section{Enumerators}

Questionnaires were enumerator-administered. The enumerators for the study consisted of a 31-year-old 'White' male lecturer and four university students, ranging in age from 21 to 26 . The students included three males and one female, three 'Black Africans' and one 'Coloured' person. Enumerators received half a day of training to familiarize themselves with the purpose and methodlogy of the study, as well as the structure and content of the questionnaire. A pilot survey was conducted at an entrance to a building on a university campus to allow an opportunity for honing sampling and interview skills. The students were instructed to administer the questionnaire entirely in English, if possible. However, if the respondent could not understand the questions in English, the enumerator was allowed to clarify it in the respondent's mother tongue, where possible.

Smith and Hyman (1950) were among the first to discuss the biasing effect that an interviewer may have on interviewee responses, known as the interviewer effect. By adhering to techniques such as those proposed by Dohrenwend, Colombotos and Dohrenwend (1968), Cannell, Miller and Oksenberg (1981), and Fowler (1990), interviewer effects can be mitigated but 
not eliminated, since even the interviewers' race and sex can affect responses (Cotter, Cohen \& Coulter 1982; Huddy, Billig, Bracciodieta, Hoeffler, Moynihan \& Pugliani 1997). A comparison of results across enumerators (not reported herein) suggests that some interviewer effect was present in this study.

\section{Results and discussion}

This section first profiles the demographic and religion/worldview characteristics of the study population and then undertakes a statistical analysis of associations between the variables. All graphs and statistics were produced, using R statistical software (R Core Team 2018).

\section{Demographic profile}

The sample of $n=513$ respondents was roughly equally distributed across the five malls. Table 2 summarizes the demographic characteristics of the sample. The sample is almost equally split between males and females and predominantly made up of younger people (median age=27). The sample consisted almost entirely of people who self-identify as 'Black Africans' or 'Coloureds'. A slight majority of respondents identified isiXhosa as their home language, while Afrikaans and English made up almost all of the remainder. Less than half of the respondents have completed secondary school and only $13 \%$ have a tertiary qualification.

\begin{tabular}{|c|l|l|}
\hline $\begin{array}{l}\text { Demographic } \\
\text { characteristic }\end{array}$ & $\begin{array}{l}\text { Sample proportion } \\
\text { (as \%; actual frequency } \\
\text { in square brackets) }\end{array}$ & $\begin{array}{l}\text { 95\% multinomial } \\
\text { confidence interval (as \%) }\end{array}$ \\
\hline Sex & & \\
\hline Male & $52.8[268]$ & $(48.4,57.4)$ \\
\hline Female & $47.2[240]$ & $(42.9,51.9)$ \\
\hline Population group & & \\
\hline 'Black African' & $56.2[282]$ & $(51.8,60.8)$ \\
\hline 'Coloured' & $39.8[200]$ & $(35.5,44.5)$ \\
\hline 'Indian or Asian' & $0.797[4]$ & $(0,5.43)$ \\
\hline 'White' & $0[0]$ & $(0,4.63)$ \\
\hline Other & $3.19[16]$ & $(0,7.82)$ \\
\hline Home language & & \\
\hline IsiXhosa & $52.1[258]$ & $(47.7,56.9)$ \\
\hline
\end{tabular}


Farrar, Falake, Mebaley, Moya \& Rudolph

\begin{tabular}{|l|l|l|}
\hline $\begin{array}{l}\text { Demographic } \\
\text { characteristic }\end{array}$ & $\begin{array}{l}\text { Sample proportion } \\
\text { (as \%; actual frequency } \\
\text { in square brackets) }\end{array}$ & $\begin{array}{l}\text { 95\% multinomial } \\
\text { confidence interval (as \%) }\end{array}$ \\
\hline Afrikaans & $27.1[134]$ & $(22.6,31.8)$ \\
\hline English & $17.2[85]$ & $(17.2,12.7)$ \\
\hline Other & $3.64[18]$ & $(0,8.38)$ \\
\hline Age group & & \\
\hline $15-19$ & $20.9[105]$ & $(16.5,25.5)$ \\
\hline $20-29$ & $38.8[195]$ & $(34.5,43.4)$ \\
\hline $30-39$ & $16.9[85]$ & $(12.5,21.5)$ \\
\hline $40-49$ & $9.76[49]$ & $(5.38,14.3)$ \\
\hline $50-59$ & $7.57[38]$ & $(3.19,12.1)$ \\
\hline $60-69$ & $4.58[23]$ & $(0.199,9.15)$ \\
\hline $70-79$ & $1.39[7]$ & $(0,5.96)$ \\
\hline Nationality & & \\
\hline South African & $97.6[482]$ & $(96.9,99.0)$ \\
\hline Other & $2.43[12]$ & $(1.42,3.82)$ \\
\hline $\begin{array}{l}\text { Highest education } \\
\text { level completed }\end{array}$ & & \\
\hline Primary or less & $5.11[26]$ & $(0.589,9.76)$ \\
\hline Some secondary & $48.3[246]$ & $(43.8,53.0)$ \\
\hline Matric & $33.6[171]$ & $(29.1,38.2)$ \\
\hline Some tertiary & $13.0[66]$ & $(8.45,17.6)$ \\
\hline
\end{tabular}

Table 2: Estimated demographic characteristics of the study population.

\section{Religion and worldview profile}

Table 3 shows indicators of the religious affiliation and participation in religious activities. Three religions (Christianity, African Traditional Religion, and Islam) account for $97.5 \%$ of the sample, with nearly seven in ten respondents self-identifying as Christian. Notably, only $1.6 \%$ of the respondents selfidentified as 'not religious'. This contrasts with the United States and Western Europe, where the percentage of people self-identifying as non-religious has increased well into the double digits in recent decades (Lužný \& Navrátilov 2001; Hout \& Fischer 2002; Crockett \& Voas 2006; Baker \& Smith 2009). It may also contrast with other estimates of the percentage of non-religious people in Cape Town as a whole (3.7\%; Statistics South Africa 2016; authors' own analysis of data) and in South Africa (6\%; Pew Forum 2010:132), though 
only the difference with South Africa is statistically significant ( $p$-value= 0.00012; $p$-value for comparison with Cape Town is 0.018).

Due to the denominational diversity within Christianity, Christian respondents were asked to indicate their denominational affiliation. Eleven denominations garnered more than $2 \%$ among Christians and the 'Other' category comprised $10.6 \%$. The three most popular denominations are Apostolic (including the 'New' and 'Old' Apostolic Churches) at 23.1\%, Pentecostal at $16.6 \%$, and Zion Christian Church (ZCC) - the largest Africaninitiated Christian group in South Africa (Oosthuizen 1997) - at 9.1\%. With the order of Pentecostal and ZCC reversed, these were also the three largest denominations in South Africa as a whole, according to the 2001 census (Department of Government Communication and Information System 2011).

There is a strong culture of religious activity in the Cape Flats. 51.2\% of the respondents report that they attend religious services at least once per week, which is very close to the $53.2 \%$ figure obtained in the 2015 General Household Survey for Cape Town as a whole (Statistics South Africa 2016; authors' own analysis). Only $12.8 \%$ attend a religious service less than once a year or never. About half of the respondents report that they pray several times per day, and three-quarters pray at least once per day. The reading of sacred religious texts is less prevalent: Only about one-third report doing so at least once per day, while nearly $70 \%$ report doing so at least once per week.

\begin{tabular}{|l|l|l|}
\hline Characteristic & $\begin{array}{l}\text { Sample proportion (as \%; } \\
\text { actual frequency in square } \\
\text { brackets) }\end{array}$ & $\begin{array}{l}\text { 95\% multinomial } \\
\text { confidence interval (as \%) }\end{array}$ \\
\hline Religion & & \\
\hline Christianity & $69.4[351]$ & $(65.6,73.5)$ \\
\hline $\begin{array}{l}\text { African Tradi- } \\
\text { tional Religion }\end{array}$ & $16.4[83]$ & $(12.6,20.5)$ \\
\hline Islam & $11.7[59]$ & $(7.91,15.8)$ \\
\hline Not religious & $1.58[8]$ & $(0,5.71)$ \\
\hline Other & $0.988[5]$ & $(0,5.12)$ \\
\hline $\begin{array}{l}\text { Christian denomi- } \\
\text { nation or group }\end{array}$ & & \\
\hline Apostolic & $23.1[81]$ & $(18.6,28.0)$ \\
\hline Pentecostal & $16.6[58]$ & $(12.0,21.5)$ \\
\hline
\end{tabular}


Farrar, Falake, Mebaley, Moya \& Rudolph

\begin{tabular}{|c|c|c|}
\hline Characteristic & $\begin{array}{l}\text { Sample proportion (as \%; } \\
\text { actual frequency in square } \\
\text { brackets) }\end{array}$ & $\begin{array}{l}95 \% \text { multinomial } \\
\text { confidence interval (as \%) }\end{array}$ \\
\hline $\begin{array}{l}\text { Zion Christian } \\
\text { Church }\end{array}$ & $9.14[32]$ & $(4.57,14.0)$ \\
\hline Anglican & $7.71[27]$ & $(3.14,12.6)$ \\
\hline Methodist & $7.71[27]$ & $(3.14,12.6)$ \\
\hline Baptist & $6.00[21]$ & $(1.43,10.9)$ \\
\hline Roman Catholic & $6.00[21]$ & $(1.43,10.9)$ \\
\hline $\begin{array}{l}\text { Seventh Day } \\
\text { Adventist }\end{array}$ & $4.29[15]$ & $(0,9.18)$ \\
\hline Presbyterian & $3.14[11]$ & $(0,8.04)$ \\
\hline Congregational & $2.86[10]$ & $(0,7.75)$ \\
\hline Dutch Reformed & $2.00[7]$ & $(0,6.9)$ \\
\hline Lutheran & $0.857[3]$ & $(0,5.75)$ \\
\hline Other & $10.6[37]$ & $(6.0,15.5)$ \\
\hline \multicolumn{3}{|l|}{$\begin{array}{l}\text { Frequency of } \\
\text { attendance at } \\
\text { religious services }\end{array}$} \\
\hline Never & $8.71[44]$ & $(4.55,13)$ \\
\hline $\begin{array}{l}\text { Less than once } \\
\text { per year }\end{array}$ & $4.16[21]$ & $(0,8.49)$ \\
\hline $\begin{array}{l}\text { About once or } \\
\text { twice per year }\end{array}$ & $5.74[29]$ & $(1.58,10.1)$ \\
\hline $\begin{array}{l}\text { Several times per } \\
\text { year }\end{array}$ & $6.73[34]$ & $(2.57,11.1)$ \\
\hline $\begin{array}{l}\text { About once per } \\
\text { month }\end{array}$ & $3.37[17]$ & $(0,7.69)$ \\
\hline $\begin{array}{l}2-3 \text { times per } \\
\text { month }\end{array}$ & $10.5[53]$ & $(6.34,14.8)$ \\
\hline $\begin{array}{l}\text { Nearly every } \\
\text { week }\end{array}$ & $6.93[35]$ & $(2.77,11.3)$ \\
\hline Every week & $31.3[158]$ & $(27.1,35.6)$ \\
\hline $\begin{array}{l}\text { Several times per } \\
\text { week }\end{array}$ & $20[101]$ & $(15.8,24.3)$ \\
\hline Don't know & $2.57[13]$ & $(0,6.9)$ \\
\hline \multicolumn{3}{|l|}{$\begin{array}{l}\text { Frequency of } \\
\text { praying }\end{array}$} \\
\hline Never & $2.19[11]$ & $(0,6.78)$ \\
\hline
\end{tabular}


A Mall Intercept Survey on Religion and Worldview in the Cape Flats

\begin{tabular}{|l|l|l|}
\hline Characteristic & $\begin{array}{l}\text { Sample proportion (as \%; } \\
\text { actual frequency in square } \\
\text { brackets) }\end{array}$ & $\begin{array}{l}\text { 95\% multinomial } \\
\text { confidence interval (as \%) }\end{array}$ \\
\hline $\begin{array}{l}\text { Less than once } \\
\text { per week }\end{array}$ & $3.38[17]$ & $(0,7.97)$ \\
\hline Once per week & $5.37[27]$ & $(0.994,9.96)$ \\
\hline $\begin{array}{l}\text { Several times per } \\
\text { week }\end{array}$ & $11.3[57]$ & $(6.96,15.9)$ \\
\hline Once per day & $24.9[125]$ & $(20.5,29.4)$ \\
\hline $\begin{array}{l}\text { Several times per } \\
\text { day }\end{array}$ & $50.5[254]$ & $(46.5,55.1)$ \\
\hline Don't know & $2.39[12]$ & $(0,6.98)$ \\
\hline $\begin{array}{l}\text { Frequency of } \\
\text { reading a sacred } \\
\text { religious text }\end{array}$ & $13.1[65]$ & $(9.05,17.5)$ \\
\hline Never & $17.3[86]$ & $(13.3,21.7)$ \\
\hline $\begin{array}{l}\text { Less than once } \\
\text { per week }\end{array}$ & $14.1[70]$ & $(10.1,18.5)$ \\
\hline Once per week & $17.7[88]$ & $(13.7,22.1)$ \\
\hline $\begin{array}{l}\text { Several times per } \\
\text { week }\end{array}$ & $15.3[76]$ & $(11.3,19.7)$ \\
\hline Once per day & $18.5[92]$ & $(14.5,22.9)$ \\
\hline $\begin{array}{l}\text { Several times per } \\
\text { day }\end{array}$ & $4.02[20]$ & $(0,8.45)$ \\
\hline Don't know & & \\
\hline Tabs Est & & \\
\hline
\end{tabular}

Table 3: Estimated religious affiliation and religious activity characteristics of the study population.

Respondents' views of God were categorized as theistic, deistic, pantheistic, agnostic, or atheistic, by asking them to choose which of the five statements taken from Zinnbauer et al. (1997) best described their beliefs. The results displayed in Table 4 indicate that the theistic and pantheistic views were most popular. Agnostic and atheistic beliefs were very infrequent. 
Farrar, Falake, Mebaley, Moya \& Rudolph

\begin{tabular}{|c|c|c|c|}
\hline Statement & $\begin{array}{l}\text { View } \\
\text { represented }\end{array}$ & $\begin{array}{l}\text { Sample } \\
\text { proportion } \\
\text { (as \%; actual } \\
\text { frequency in } \\
\text { square } \\
\text { brackets) }\end{array}$ & $\begin{array}{l}95 \% \\
\text { multinomial } \\
\text { confidence } \\
\text { interval (as } \\
\%)\end{array}$ \\
\hline $\begin{array}{l}\text { I believe God is a personal } \\
\text { being who reigns over all } \\
\text { creation, who looks after us } \\
\text { and listens to our prayers and } \\
\text { praises. }\end{array}$ & Theistic & $68.9[326]$ & $(64.9,73.1)$ \\
\hline $\begin{array}{l}\text { I believe God created the world } \\
\text { and everything in it and then } \\
\text { left us to fend for ourselves. } \\
\text { God is no longer involved in } \\
\text { the happenings of this world. }\end{array}$ & Deistic & $11.0[52]$ & $(6.98,15.2)$ \\
\hline $\begin{array}{l}\text { I believe that God is one with } \\
\text { the universe. I see God in } \\
\text { nature and in every person I } \\
\text { meet. }\end{array}$ & Pantheistic & $17.3[82]$ & $(13.3,21.5)$ \\
\hline $\begin{array}{l}\text { I am not sure what or who God } \\
\text { is. I often wonder if there is a } \\
\text { God, but I do not think that I } \\
\text { will ever know for sure. }\end{array}$ & Agnostic & $2.33[11]$ & $(0,6.51)$ \\
\hline $\begin{array}{l}\text { I do not believe there is a God. } \\
\text { There is no higher power that } \\
\text { can intervene in our lives. }\end{array}$ & Atheistic & $0.423[2]$ & $(0,4.61)$ \\
\hline
\end{tabular}

Table 4: Estimated representation of different beliefs about God in the study population.

Six items on a five-point 'Agree/Disagree' Likert scale - adapted from the ISSP Research Group (2012) and Vermeer and Van der Ven (2004) - were used to assess respondents' self-assessed degree of religiosity and spirituality as well as religious pluralism versus exclusivism. The results, displayed in Figure 1, indicate that over $80 \%$ of the respondents agree or strongly agree that they consider themselves as religious. A slightly lower percentage (79\%) agrees or strongly agrees that they consider themselves spiritual. One certainly does not find the 'spiritual-but-not-religious' dichotomy that has been observed in Western Europe (Houtman \& Aupers 2007). Concerning religious pluralism and exclusivism, many respondents agree that their religion is the only way 
to true salvation and that other religions contain only part of the truth, but simultaneously agree that different religions are different ways to the same salvation and that religions are all directed at the same truth. Many respondents seem to hold these viewpoints in tension, affirming the unique merits of their own religion while not wishing to denigrate other religions.

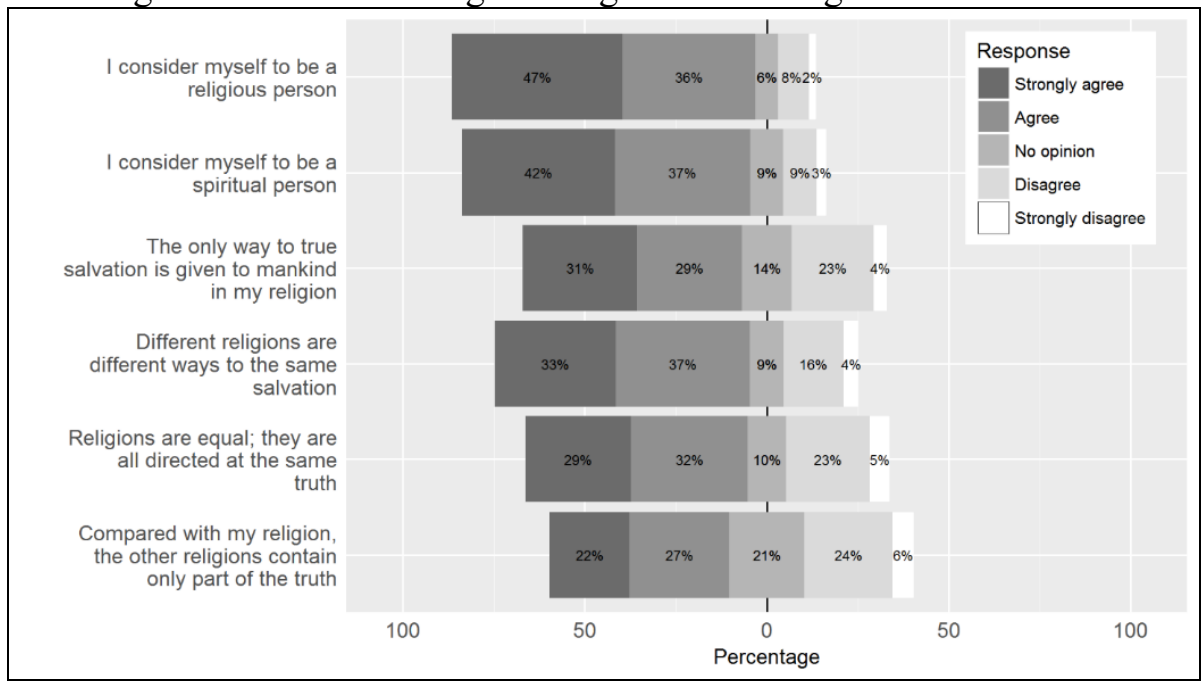

Figure 1: Results of religiosity, spirituality, and religious pluralism vs. exclusivism questions.

Christian-Abrahamic supernaturalism was measured using a nine-item scale adapted from Jong et al. (2013). Results (shown in Figure 2) indicate a high degree of Christian-Abrahamic supernaturalism. Most respondents believe that supernatural phenomena such as God, Satan, angels, demons, a/the Holy Spirit, immortal souls, heaven, hell, and miracles are real. A belief in other supernatural phenomena (witchcraft/magic, communication with the dead, foretelling future, ancestral guidance, and star signs) was less pronounced (Figure 3 ), although - with the exception of star signs - all of these phenomena were considered definitely or probably real by a majority of respondents. 


\section{Farrar, Falake, Mebaley, Moya \& Rudolph}

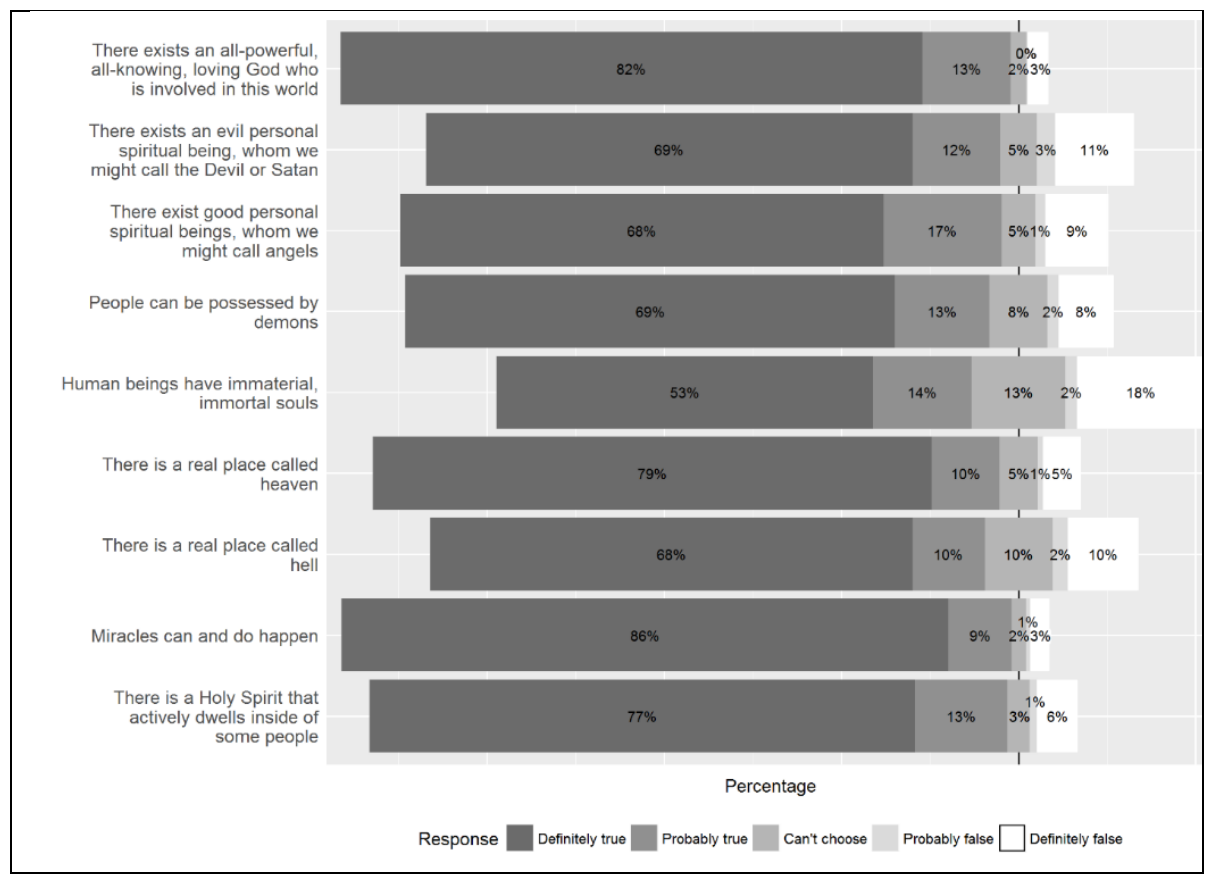

Figure 2: Results of Christian-Abrahamic supernaturalism scale questions.

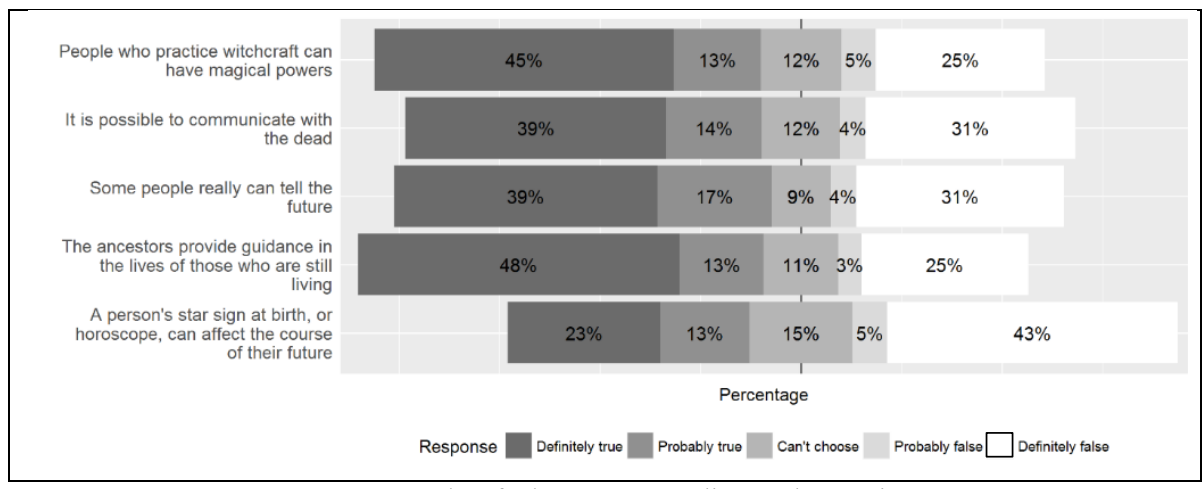

Figure 3: Results of other supernaturalism scale questions. 


\section{Associations between demographic characteristics and religion or worldview indicators}

In this section, various statistical methods are used to test for associations between the demographic characteristics and religion or worldview indicators, and between different religion or worldview indicators. For statistical details of the methods used (which are all nonparametric), see Agresti (2002), Conover (1999), Jonckheere (1954), and Dunn (1964). Due to the large number of hypothesis tests conducted in this study, a conservative significance level of 0.001 has been used throughout in order to avoid excessive accumulation of type I errors. Thus, only when the $p$-value of a test for association is below 0.001 , the null hypothesis is rejected and an association found to be present. A summary of all detected associations is given in Table 6 .

\section{Associations between demographic characteristics and religious activities}

Using the Cochran-Armitage trend test, no significant association was found between the frequency of attendance at religious services and sex ( $p$-value $=$ 0.0039). However, when Muslims are excluded from this analysis on the grounds that some Muslim communities discourage women from attending Friday prayers at mosques (Sayeed 2001), the association is statistically significant $\left(p\right.$-value $\left.=7.6 \times 10^{-5}\right)$, suggesting that non-Muslim women attend religious services more frequently than non-Muslim men. The data suggest that females (across all religious affiliations) pray more frequently than males ( $p$ value $\left.=1.5 \times 10^{-4}\right)$. However, there is no evidence of a difference between the sexes in the frequency of reading sacred religious texts $(p$-value $=0.48)$. No associations were found between the three indicators - frequency of attendance at religious services, prayer, and reading of sacred texts - and other demographic variables such as population group and education level.

Kendall's nonparametric correlation coefficient was used to test for an association between religious behaviors and age. There is insufficient evidence to claim a positive association between age and frequency of attendance at religious services $(p$-value $=0.17)$ or between age and frequency of reading sacred religious texts ( $p$-value $=0.0057)$, but the data do suggest a positive association between age and frequency of prayer $\left(p\right.$-value $\left.=6.1 \times 10^{-11}\right)$.

\section{Associations between demographic characteristics and religious affiliation}

Statistical tests were conducted for the association between religious affiliation and certain other demographic and religiosity variables. Only three religious 
affiliations were considered (Christianity, African Traditional Religion, and Islam) due to the low frequencies of other affiliations.

The Pearson chi-squared test for independence was used to check for an association between religious affiliation and other demographic variables (sex, education level, population group). No association was found between religious affiliation and sex $(p$-value $=0.15)$ or between religious affiliation and education level ( $p$-value $=0.24)$. However, a strong association was found between religious affiliation and population group $\left(p\right.$-value $\left.=7.2 \times 10^{-27}\right)$. Specifically, $100 \%$ of respondents who self-identified as African Traditional Religion were 'Black Africans' and $86 \%$ of respondents who self-identified as Muslim were 'Coloureds'. Respondents self-identifying as Christian were more evenly divided between population groups.

The Kruskal-Wallis nonparametric rank sum test was used to check for any difference in frequency of the religious behavior between the three religious affiliations, and if a difference was detected, multiple comparisons were conducted using Dunn's test with the Holm correction of familywise error rate. For attendance at religious services, the null hypothesis of no difference in frequency across religious affiliations was rejected, using the KruskalWallis test $\left(p\right.$-value $\left.=1.7 \times 10^{-5}\right)$. Dunn's test found that both Christians ( $p$ value $\left.=3.8 \times 10^{-5}\right)$ and Muslims $\left(p\right.$-value $\left.=2.1 \times 10^{-4}\right)$ attend religious services more frequently than African Traditional Religionists, but no significant difference was found between Christians and Muslims ( $p$-value=0.34). As for prayer, the null hypothesis of no difference in frequency across religious affiliations was rejected, using the Kruskal-Wallis test $\left(p\right.$-value $\left.=4.7 \times 10^{-4}\right)$. Dunn's test found that Muslims pray more frequently than both the African Traditional Religionists $\left(p\right.$-value $\left.=7.1 \times 10^{-4}\right)$ and Christians $\left(p\right.$-value $\left.=8.0 \times 10^{-4}\right)$, likely due to diligent observance of the Islamic pillar of șalät. No significant difference was found in prayer frequency between African Traditional Religionists and Christians $(p$-value $=0.29)$. For the reading of sacred religious texts, the null hypothesis of no difference in frequency across religious affiliations was rejected, using the Kruskal-Wallis test $\left(p\right.$-value $\left.=3.4 \times 10^{-5}\right)$. Dunn's test found that Muslims read sacred religious texts more frequently than African Traditional Religionists $\left(p\right.$-value $\left.=1.7 \times 10^{-5}\right)$, but found no statistically significant differrence in frequency of reading sacred religious texts between Muslims and Christians $(p$-value $=0.0021)$ or between Christians and African Traditional Religionists $(p$-value $=0.010)$. The Kruskal-Wallis test found no significant difference between the religious affiliations in a self-reported degree of 
religiosity ( $p$-value $=0.78)$ or in a self-reported degree of spirituality ( $p$ value $=0.64$ ). In summary, while adherents to the three main religions represented in the Cape Flats appear not to differ in the degree to which they consider themselves religious or spiritual, Muslims appear to participate most frequently in the religious behaviors measured, particularly prayer.

\section{Predictors of Christian-Abrahamic supernaturalism}

In order to analyze the degree of Christian-Abrahamic supernaturalism, responses for each of the nine relevant questions were scored numerically (Definitely true $=4$, Probably true $=3$, Can't choose $=2$, Probably false $=1$, Definitely false $=0$ ) and these scores were aggregated for each respondent, giving an overall score between 0 and 36, with a higher score representing a stronger degree of belief in these phenomena. Associations between these aggregated supernaturalism scores and certain demographic and religion variables were then tested, using the Kruskal-Wallis test and, where necessary, Dunn's multiple comparison test. No difference in degree of Christian-Abrahamic supernaturalism was found between the sexes ( $p$-value $=0.42)$, between people who had completed secondary school and those who had not $(p$-value $=0.81)$, or between population groups $(p$-value $=0.0018)$. Using Kendall's nonparametric correlation coefficient (since the Kruskal-Wallis test is not appropriate for numeric independent variables), a positive association was found between the degree of Christian-Abrahamic supernaturalism and age $\left(p\right.$-value $\left.=8.6 \times 10^{-8}\right)$.

Turning to the association between the degree of Christian-Abrahamic supernaturalism and other religion variables, the finding from the KruskalWallis test was that supernaturalism scores are not the same across all religious affiliations $\left(p\right.$-value $\left.=1.2 \times 10^{-5}\right)$. Christians specifically tend to have higher Christian-Abrahamic supernaturalism scores than African Traditional Religionists $\left(p\right.$-value $\left.=7.2 \times 10^{-6}\right)$. The differences between Christians and Muslims $(p$-value $=0.17)$ and between Muslims and African Traditional Religionists $(p-$ value $=0.051$ ) were not statistically significant. The individual Christian-Abrahamic supernaturalism items on which Christians and African Traditional Religionists had the greatest degree of difference in belief were the existence of a real place called hell, and, to a lesser extent, the existence of a real place called heaven, and the existence of good spiritual beings that might be called angels.

The Jonckheere-Terpstra test for ordered differences was used to check for an association between religiosity and degree of Christian-Abrahamic supernaturalism. Only self-identifying Christian and Muslim respondents 
were included in this analysis to avoid confounding a religiosity-supernaturalism association with the association between supernaturalism and religious affiliation just noted. No statistically significant positive association was found between a self-reported religiosity and Christian-Abrahamic supernaturalism score $(p$-value $=0.038)$, but a statistically significant positive association was found between the self-reported spirituality and Christian-Abrahamic supernaturalism score $\left(p\right.$-value $\left.=5.1 \times 10^{-4}\right)$, that is, Christian and Muslim respondents who consider themselves more spiritual are more likely to believe in supernatural aspects of a Christian-Abrahamic worldview. No association between the frequency of attendance at religious services and Christian-Abrahamic supernaturalism score ( $p$-value $=0.027$ ), or between the frequency of reading sacred religious texts and Christian-Abrahamic supernaturalism score ( $p$-value $=0.094)$ was detected, although a positive association between the frequency of prayer and Christian-Abrahamic supernaturalism score was found $\left(p\right.$-value $\left.=2.6 \times 10^{-5}\right)$. This indicates that Christians and Muslims who pray more frequently tend to believe more strongly in supernatural aspects of a ChristianAbrahamic worldview.

\section{Predictors of other supernaturalism}

A separate analysis was undertaken of those supernaturalism items not necessarily related to a Christian-Abrahamic worldview (the efficacy of witchcraft/magic, possibility of communication with the dead, possibility of ancestral guidance of the living, possibility of foretelling the future, and the effect of a person's star sign on their future). Some of these items are related to African Traditional Religion, but the scale was not conceived of specifically with this religion in mind; hence its generic name 'other supernaturalism' (which is not intended as a value judgment). An 'other supernaturalism' score was obtained by scoring and aggregating responses to the five 'other supernaturalism' items, giving an overall score between zero and 20, with a higher score representing a stronger degree of belief in these phenomena. Using the Kruskal-Wallis test, it was concluded that there is no difference in degree of other supernaturalism between the sexes $(p$-value $=0.13)$ or between people who had completed secondary school and those who had not ( $p$-value $=0.82$ ). Using Kendall's nonparametric correlation coefficient, no association was found between the degree of other supernaturalism and age $(p$-value $=0.46)$. However, a strong association was detected between the other supernaturalism score and population groups ( $p$-value $\left.=5.0 \times 10^{-17}\right)$, with 'Black Africans' 
scoring higher than the 'Coloured' people. This ethnographic difference is not reducible to differences in religious affiliation alone, since this association was found even between 'Black African' Christians and 'Coloured' Christians ( $p$ value $=1.1 \times 10^{-9}$ ). It most likely indicates the influence of ancestral rituals on the religious experience of self-identifying 'Black African' Christians in the Cape Flats. A statistically significant difference was found between 'Coloured' and 'Black African' respondents for all of the individual 'other supernaturalism' items, except for the star sign item.

An association between other supernaturalism scores and religious affiliation was also found (Kruskal-Wallis $p$-value $=1.9 \times 10^{-11}$ ). African Traditional Religionists had the highest other supernaturalism score, followed by Christians, while Muslims had the lowest; all of these differences were statistically significant. The African Traditional Religionists had stronger beliefs than other religions in the efficacy of witchcraft/magic and the possibility of guidance from deceased ancestors. Christians also had stronger beliefs than Muslims in the efficacy of witchcraft/magic and the possibility of foretelling the future.

\begin{tabular}{|l|l|l|l|l|}
\hline First variable & $\begin{array}{l}\text { Second } \\
\text { variable }\end{array}$ & $\begin{array}{l}\text { Nature of } \\
\text { association }\end{array}$ & $\begin{array}{l}\text { Statistical } \\
\text { test used }\end{array}$ & p-value \\
\hline $\begin{array}{l}\text { Frequency of } \\
\text { attendance at } \\
\text { religious } \\
\text { services }\end{array}$ & Sex & $\begin{array}{l}\text { When Muslims are } \\
\text { excluded, females } \\
\text { tend to attend reli- } \\
\text { gious services more } \\
\text { frequently than } \\
\text { males. }\end{array}$ & $\begin{array}{l}\text { Cochran- } \\
\text { Armitage }\end{array}$ & $7.6 \times 10^{-5}$ \\
& $\begin{array}{l}\text { Religious } \\
\text { affiliation }\end{array}$ & $\begin{array}{l}\text { Muslims and Chris- } \\
\text { tians both tend to } \\
\text { attend religious ser- } \\
\text { vices more frequently } \\
\text { than African Traditio- } \\
\text { nal Religionists. }\end{array}$ & $\begin{array}{l}\text { Kruskal- } \\
\text { Wallis; } \\
\text { Dunn }\end{array}$ & $1.7 \times 10^{-5}$ \\
\hline $\begin{array}{l}\text { Frequency of } \\
\text { prayer }\end{array}$ & Sex & $\begin{array}{l}\text { Females tend to pray } \\
\text { more frequently than } \\
\text { males. }\end{array}$ & $\begin{array}{l}\text { Cochran- } \\
\text { Armitage }\end{array}$ & $1.5 \times 10^{-4}$ \\
\cline { 2 - 5 } & Age & $\begin{array}{l}\text { The frequency of } \\
\text { prayer increases with } \\
\text { age. }\end{array}$ & Kendall & $6.1 \times 10^{-11}$ \\
\hline
\end{tabular}


Farrar, Falake, Mebaley, Moya \& Rudolph

\begin{tabular}{|c|c|c|c|c|}
\hline First variable & $\begin{array}{l}\text { Second } \\
\text { variable }\end{array}$ & $\begin{array}{l}\text { Nature of } \\
\text { association }\end{array}$ & $\begin{array}{l}\text { Statistical } \\
\text { test used }\end{array}$ & $p$-value \\
\hline & $\begin{array}{l}\text { Religious } \\
\text { affiliation }\end{array}$ & $\begin{array}{l}\text { Muslims tend to pray } \\
\text { more frequently than } \\
\text { Christians and } \\
\text { African Traditional } \\
\text { Religionists. }\end{array}$ & $\begin{array}{l}\text { Kruskal- } \\
\text { Wallis; } \\
\text { Dunn }\end{array}$ & $4.7 \times 10^{-4}$ \\
\hline $\begin{array}{l}\text { Frequency of } \\
\text { reading sacred } \\
\text { religious texts }\end{array}$ & $\begin{array}{l}\text { Religious } \\
\text { affiliation }\end{array}$ & $\begin{array}{l}\text { Muslims tend to read } \\
\text { their sacred religious } \\
\text { texts more frequently } \\
\text { than African Tradi- } \\
\text { tional Religionists. }\end{array}$ & $\begin{array}{l}\text { Kruskal- } \\
\text { Wallis; } \\
\text { Dunn }\end{array}$ & $3.4 \times 10^{-5}$ \\
\hline $\begin{array}{l}\text { Religious } \\
\text { affiliation }\end{array}$ & $\begin{array}{l}\text { Population } \\
\text { group }\end{array}$ & $\begin{array}{l}\text { 'Black African' peo- } \\
\text { ple are more likely } \\
\text { than 'Coloured' peo- } \\
\text { ple to adhere to the } \\
\text { African Traditional } \\
\text { Religion. 'Coloured' } \\
\text { people are more } \\
\text { likely than 'Black } \\
\text { African' people to } \\
\text { adhere to Islam. }\end{array}$ & $\begin{array}{l}\text { Pearson } \\
\text { chi- } \\
\text { squared }\end{array}$ & $7.2 \times 10^{-27}$ \\
\hline \multirow{3}{*}{$\begin{array}{l}\text { Christian- } \\
\text { Abrahamic } \\
\text { supernaturalism } \\
\text { score (measures } \\
\text { degree of belief } \\
\text { in supernatural } \\
\text { aspects of a } \\
\text { Christian- } \\
\text { Abrahamic } \\
\text { worldview) }\end{array}$} & Age & $\begin{array}{l}\text { The degree of belief } \\
\text { in supernatural } \\
\text { aspects of Christian- } \\
\text { Abrahamic world- } \\
\text { view increases with } \\
\text { age. }\end{array}$ & Kendall & $8.6 \times 10^{-8}$ \\
\hline & $\begin{array}{l}\text { Religious } \\
\text { affiliation }\end{array}$ & $\begin{array}{l}\text { Christians tend to } \\
\text { have higher Chris- } \\
\text { tian-Abrahamic } \\
\text { supernaturalism } \\
\text { scores (particularly } \\
\text { hell, heaven, and } \\
\text { angels) than African } \\
\text { Traditional } \\
\text { Religionists. }\end{array}$ & $\begin{array}{l}\text { Kruskal- } \\
\text { Wallis; } \\
\text { Dunn }\end{array}$ & $1.2 \times 10^{-5}$ \\
\hline & Spirituality & $\begin{array}{l}\text { Christians and Mus- } \\
\text { lims with a higher } \\
\text { degree of self- }\end{array}$ & $\begin{array}{l}\text { Jonckheere } \\
\text {-Terpstra }\end{array}$ & $5.1 \times 10^{-4}$ \\
\hline
\end{tabular}




\begin{tabular}{|c|c|c|c|c|}
\hline First variable & $\begin{array}{l}\text { Second } \\
\text { variable }\end{array}$ & $\begin{array}{l}\text { Nature of } \\
\text { association }\end{array}$ & $\begin{array}{l}\text { Statistical } \\
\text { test used }\end{array}$ & $p$-value \\
\hline & & $\begin{array}{l}\text { reported spirituality } \\
\text { tend to have higher } \\
\text { Christian-Abrahamic } \\
\text { supernaturalism } \\
\text { scores than Christians } \\
\text { and Muslims with a } \\
\text { lower degree of self- } \\
\text { reported spirituality. }\end{array}$ & & \\
\hline & $\begin{array}{l}\text { Frequency } \\
\text { of prayer }\end{array}$ & $\begin{array}{l}\text { Christians and Mus- } \\
\text { lims who pray more } \\
\text { frequently tend to } \\
\text { have higher Chris- } \\
\text { tian-Abrahamic } \\
\text { supernaturalism } \\
\text { scores than Christians } \\
\text { and Muslims who } \\
\text { pray less frequently. }\end{array}$ & $\begin{array}{l}\text { Jonckheere } \\
\text {-Terpstra }\end{array}$ & $2.6 \times 10^{-5}$ \\
\hline \multirow[t]{2}{*}{$\begin{array}{l}\text { Other super- } \\
\text { naturalism } \\
\text { score (measures } \\
\text { degree of belief } \\
\text { in supernatural } \\
\text { or paranormal } \\
\text { phenomena not } \\
\text { directly related } \\
\text { to a Christian- } \\
\text { Abrahamic } \\
\text { worldview) }\end{array}$} & $\begin{array}{l}\text { Population } \\
\text { group }\end{array}$ & $\begin{array}{l}\text { 'Black African' } \\
\text { people tend to have } \\
\text { higher 'other super- } \\
\text { naturalism' scores } \\
\text { than 'Coloured' } \\
\text { people; also, 'Black } \\
\text { African' Christians } \\
\text { tend to have higher } \\
\text { 'other supernatural- } \\
\text { ism' scores than } \\
\text { 'Coloured' Chris- } \\
\text { tians. }\end{array}$ & $\begin{array}{l}\text { Kruskal- } \\
\text { Wallis; } \\
\text { Dunn }\end{array}$ & $5.0 \times 10^{-17}$ \\
\hline & $\begin{array}{l}\text { Religious } \\
\text { affiliation }\end{array}$ & $\begin{array}{l}\text { African Traditional } \\
\text { Religionists tend to } \\
\text { have the highest } \\
\text { 'other supernatural- } \\
\text { ism' scores, followed } \\
\text { by Christians, follow- } \\
\text { ed by Muslims. The } \\
\text { differences are } \\
\text { mainly related to a }\end{array}$ & $\begin{array}{l}\text { Kruskal- } \\
\text { Wallis; } \\
\text { Dunn }\end{array}$ & $1.9 \times 10^{-11}$ \\
\hline
\end{tabular}


Farrar, Falake, Mebaley, Moya \& Rudolph

\begin{tabular}{|l|l|l|l|l|}
\hline First variable & $\begin{array}{l}\text { Second } \\
\text { variable }\end{array}$ & $\begin{array}{l}\text { Nature of } \\
\text { association }\end{array}$ & $\begin{array}{l}\text { Statistical } \\
\text { test used }\end{array}$ & $p$-value \\
\hline & & $\begin{array}{l}\text { belief in the efficacy } \\
\text { of witchcraft/magic, } \\
\text { the possibility of } \\
\text { guidance by deceased } \\
\text { ancestors, and the } \\
\text { possibility of } \\
\text { foretelling the future. }\end{array}$ & & \\
& & & \\
\hline
\end{tabular}

Table 5: Associations between variables that are statistically significant at 0.001 level.

\section{Conclusion}

Broadly speaking, the contribution of this study is twofold. First, it explores the use of the mall intercept sampling methodology for profiling the religious beliefs, practices, and worldview of a population in a developing world context, where other modes of data collection are either very expensive (household surveys) or impractical (telephone or internet surveys). This method was found to be a feasible and cost-effective means of conducting a religion survey. However, further research is needed to find ways to improve the response rate specifically in the context of the South African shopping mall.

Second, the study contributes to an enhanced understanding of the religious beliefs, practices, and worldviews of residents of the Cape Flats. The data suggest that the majority of the study population self-identify as Christian, with sizable minorities of African Traditional Religionists and Muslims. A strong culture of prayer, reading of sacred texts, and attendance to religious services persists in the Cape Flats. The participation in these particular religious activities appears to be more pronounced among Muslims than adherents to other religions, and more pronounced among the old than the young. A belief in supernatural phenomena, particularly those traditionally identified with a Christian-Abrahamic worldview, appears to be highly prevalent in the Cape Flats, and is positively related to age.

That frequency of prayer is also positively associated with age may just hint at a decline in religiosity on the horizon. Broadly speaking, however, it is obvious that the Cape Flats area has not experienced the sharp decline in self-reported religiosity, participation in religious activities, and a belief in supernatural phenomena that has been documented in Western countries over 
the past few decades. The majority of residents are consciously and actively religious and spiritual people who retain a strongly supernatural worldview. Given the unabated vitality of religious expression and experience detected in this study, future research ought to explore the role of lived religion in the Cape Flats communities' resilience in the face of past and present forms of oppression and marginalization.

\section{References}

Adriaanse, H.J. 1999. On defining religion. In Platvoet, J.G. \& A.L. Molendijk (eds.): The pragmatics of defining religion: Contexts, concepts \& contests. Leiden: Brill.

Agresti, A. 2002. Categorical data analysis. New York: John Wiley.

Altemeyer, B. \& B. Hunsberger 1992. Authoritarianism, religious fundamentalism, quest, and prejudice. The International Journal for the Psychology of Religion 2, 2: 113-133.

Amoateng, A.Y. 1997. The structure of urban black households: New survey evidence from a coloured and an African community on the Cape Flats in the Western Cape of South Africa. African Sociological Review 1, 2: $22-40$.

Baker, J.O. 2008. Who believes in religious evil? An investigation of sociological patterns of belief in satan, hell, and demons. Review of Religious Research 50, 2: 206-220.

Baker, J.O. \& B.G. Smith 2009. The nones: Social characteristics of the religiously unaffiliated. Social Forces 87, 3: 1251-1263.

Barna, G. 2003. Think like Jesus. Nashville: Thomas Nelson.

Batson, C.D. 1976. Religion as prosocial: Agent or double agent? Journal for the Scientific Study of Religion 15, 1: 29-45.

Berrenberg, J.L. 1987. The belief in personal control scale: A measure of Godmediated and exaggerated control. Journal of Personality Assessment 51, 2: 194-206.

Blair, E. 1983. Sampling issues in trade area maps drawn from shopper surveys. Journal of Marketing 47: 98-106.

Bultmann, R. [1941] 1984. New Testament and mythology and other basic writings. Ogden, S.M. (ed.). Philadelphia: Fortress Press. 
Farrar, Falake, Mebaley, Moya \& Rudolph

Burkett, S.R. \& M. White 1974. Hellfire and delinquency: Another look. Journal for the Scientific Study of Religion 13: 455-462.

Bush, A.J. \& J.F. Hair Jr. 1985. An assessment of the mall intercept as a data collection method. Journal of Marketing Research 22: 158-167.

Bush, A.J. \& A. Parasuraman 1984. Assessing response quality: A selfdisclosure approach to assessing response quality in mall intercept and telephone interviews. Psychology \& Marketing 1, 3: 57-71.

Cannell, C.F., P.V. Miller \& O. Oksenberg 1981. Research on interviewing techniques. Sociological Methodology 12: 389-437.

City of Cape Town. 2015. Distribution of religious affiliation by population group. Available at: https://www.capetown.gov.za/en/stats/2001census/ Documents/Religious_Afiliation.mht. (Accessed on 11 December 2015.)

Clark, J.D. 1991. The association between Bible literacy and religiosity. $\mathrm{PhD}$ Dissertation, College of Education, University of North Texas, Texas.

Collins, C.J. 2006. Genesis 1-4: A Linguistic, literary, and theological commentary. Phillipsburg: P\&R Publishing.

Conover, W.J. 1999. Practical nonparametric statistics. $2^{\text {nd }}$ ed. New York: John Wiley.

Cotter, P.R., J. Cohen \& P.B. Coulter 1982. Race-of-interviewer effects in telephone interviews. Public Opinion Quarterly 46, 2: 278-284.

Crockett, A. \& D. Voas 2006. Generations of decline: Religious change in $20^{\text {th }}$ century Britain. Journal for the Scientific Study of Religion 45, 4: 567584.

De Graaf, N.D. \& M. Te Grotenhuis 2008. Traditional Christian belief and belief in the supernatural: Diverging trends in the Netherlands between 1979 and 2005? Journal for the Scientific Study of Religion 47, 4: 585598.

Department of Government Communication and Information System (GCIS) 2011. Pocket guide to South Africa 2011/12. Available at: http://www. gcis.gov.za/content/resourcecentre/sa-info/pocket-guide-south-africa20112012. (Accessed on 12 September 2018.)

Dohrenwend, B.S., J. Colombotos \& B.P. Dohrenwend 1968. Social distance and interviewer effects. Public Opinion Quarterly 32, 3: 410-422.

Dunn, O.J. 1964. Multiple comparisons using rank sums. Technometrics 6, 3: 241-252. 
Durkheim, E. [1899] 2011. Concerning the definition of religious phenomena. In Pickering, W.S.F. (ed.): Durkheim on religion: A selection of readings with bibliographies and introductory remarks. Cambridge: James Clarke \& Co.

Fowler, F.J. Jr. 1990. Standardized survey interviewing: Minimizing interviewer-related error. London: Sage.

Garland, R. 1991. The mid-point on a rating scale: Is it desirable? Marketing Bulletin 2: 66-70.

Hanciles, J.J. 2008. Beyond Christendom: Globalization, African migration, and the transformation of the West. Maryknoll: Orbis Books.

Harris, R.A. 2004. The integration of faith and learning: A worldview approach. Eugene: Wipf \& Stock.

Hornik, J. \& S. Ellis 1988. Strategies to secure compliance for a mall intercept interview. Public Opinion Quarterly 52: 539-551.

Hout, M. \& C.S. Fischer 2002. Why more Americans have no religious preference: Politics and generations. American Sociological Review 67, 2: 165-190.

Houtman, D. \& S. Aupers 2007. The spiritual turn and the decline of tradition: The spread of post-Christian spirituality in 14 Western countries, 1981 2000. Journal for the Scientific Study of Religion 46, 3: 305-320.

Houtman, D. \& P. Mascini 2002. Why do churches become empty, while New Age grows? Secularization and religious change in the Netherlands. Journal for the Scientific Study of Religion 41, 3: 455-473.

Huddy, L., J. Billig, J. Bracciodieta, L. Hoeffler, P.J. Moynihan \& P. Pugliani 1997. The effect of interviewer gender on the survey response. Political Behavior 19, 3: 197-220.

ISSP Research Group. 2012. International social survey programme: Religion III - ISSP 2008. GESIS data archive, Cologne. ZA4950 Data file Version 2.2.0. DOI: 10.4232/1.11334.

Johnson, C.C. 2016. Race, religion, and resilience in the neoliberal age. New York: Palgrave Macmillan.

Jonckheere, A.R. 1954. A distribution-free $k$-sample test again ordered alternatives. Biometrika 41: 133-145.

Jong, J., M. Bluemke \& J. Halberstadt 2013. Fear of death and supernatural beliefs: Developing a new supernatural belief scale to test the relationship. European Journal of Personality 27, 5: 495-506. 
Farrar, Falake, Mebaley, Moya \& Rudolph

Keys, R.S. 2004. The interactions between an orthodox Christian worldview and environmental attitudes and beliefs; for the purpose of developing better instructional practice in support of environmental/ecological attitudes and knowledge. PhD Dissertation, Mallinson Institute for Science Education, Western Michigan University, Michigan.

King, J.E. \& M.R. Crowther 2004. The measurement of religiosity and spirituality: Examples and issues from psychology. Journal of Organizational Change Management 17, 1: 83-101.

Lanier, D.N. 2010. Twenty-somethings in the church: The impact of a biblical worldview study. DMin Dissertation, Asbury Theological Seminary, Kentucky.

Lužný, D. \& J. Navrátilov 2001. Religion and secularisation in the Czech Republic. Czech Sociological Review 9, 1: 85-98.

McGuire, M.B. 2008. Lived religion: Faith and practice in everyday life. Oxford: Oxford University Press.

Neville, R.C. 2018. A heuristic definition of religion. In Neville, R.C. (ed.): Defining religion: Essays on philosophy of religion. Albany: SUNY Press.

Norenzayan, A. \& I.G. Hansen 2006. Belief in supernatural agents in the face of death. Personality and Social Psychology Bulletin 32, 2: 174-187.

Nowell, C. \& L.R. Stanley 1991. Length-biased sampling in mall intercept surveys. Journal of Marketing Research 28: 475-479.

Oosthuizen, G.C. 1997. Indigenous Christianity and the future of the church in South Africa. International Bulletin of Missionary Research 21, 1: 8-12. Osarchuk, M. \& S.J. Tatz 1973. Effect of induced fear of death on belief in afterlife. Journal of Personality and Social Psychology 27, 2: 256-260.

Pennycook, G., J.A. Cheyne, P. Seli, D.J. Koehler \& J.A. Fugelsang 2012. Analytic cognitive style predicts religious and paranormal belief. $\mathrm{Cog}$ nition 123: 335-346.

Pew Forum. 2010. Tolerance and tension: Islam and Christianity in subSaharan Africa. Washington, D.C.: Pew Research Center.

Preston, C.C. \& A.M. Colman 2000. Optimal number of response categories in rating scales: Reliability, validity, discriminating power, and respondent preferences. Acta Psychologica 104: 1-15.

R Core Team. 2018. R: A language and environment for statistical computing. R Foundation for Statistical Computing, Vienna, Austria. Available at: http://www.R-project.org. (Accessed on 12 September 2018.) 
Sayeed, A. 2001. Early Sunni discourse on Women's mosque attendance. International Institute for the Study of Islam in the Modern World (ISIM) Newsletter 7, 1: 10.

Schoeman, W.J. 2017, South African religious demography: The 2013 General Household Survey. HTS Teologiese Studies/Theological Studies 73(2), 7 pages, a3837. https://doi.org/10.4102/hts.v73i2.3837

Sire, J.W. 2004. Naming the elephant: Worldview as a concept. Downers Grove: InterVarsity Press.

Smith, H.L. \& H. Hyman 1950. The biasing effect of interviewer expectations on survey result. Public Opinion Quarterly 14, 3: 491-506.

Smith, T.W., M. Hout \& P.V. Marsden 1972-2012. General social survey. ICPSR 34802. Storrs, CT: Roper Center for Public Opinion Research, University of Connecticut / Ann Arbor, MI: Inter-university Consortium for Political and Social Research [distributors]. DOI:10.3886/ ICPSR34802.v1

South African Audience Research Foundation (SAARF) 2014. SAARF AMPS Jul-Dec 2014 questionnaire. Available at: http://www.saarf.co.za/ampsdscapiquestionnaires/2014/SAARF\%20AMPS\%20Jul-Dec\%202014\% 20Questionnaire.pdf. (Accessed on 12 September 2018.)

Sremac, S. \& R.R. Ganzevoort 2017. Lived religion and lived (in)tolerance. In Ganzevoort, R.R. \& S. Sremac (eds.): Lived religion and the politics of (in)tolerance. Cham: Palgrave Macmillan.

Statistics South Africa 2011a. Frequently asked questions - census 2011. Available at: http://www.statssa.gov.za/?page id=3859. (Accessed on 12 September 2018.)

Statistics South Africa 2011b. Household questionnaire A - census 2011. Available at: http://www.statssa.gov.za/census/census 2011/Census Questionnaires/Census\%202011_q_A.pdf. (Accessed on 12 September 2018.)

Statistics South Africa 2016. General Household Survey 2015. Pretoria: Statistics South Africa.

Statistics South Africa 2017. General Household Survey 2016. Pretoria: Statistics South Africa.

Steensland, B., J.Z. Park, M.D. Regnerus, L.D. Robinson, W.B. Wilcox \& R.D. Woodberry 2000. The measure of American religion: Toward improving the state of the art. Social Forces 79, 1:291-318. 
Farrar, Falake, Mebaley, Moya \& Rudolph

Sudman, S. 1980. Improving the quality of shopping center sampling. Journal of Marketing Research 17: 423-431.

Theron, P.M. \& G.A. Lotter 2009. The necessity of an integral Christian worldview: Reconnoitering the challenges for influencing the unbelieving world. Koers: Bulletin for Christian Scholarship 74, 3: 467-493.

Thompson, S.K. 1987. Sample size for estimating multinomial proportions. The American Statistician 41, 1: 42-46.

Vermeer P. \& J.A. Van der Ven 2004. Looking at the relationship between religions: An empirical study among secondary school students. Journal of Empirical Theology 17, 1: 36-59.

Weijters, B., E. Cabooter \& N. Schillewaert 2010. The effect of rating scale format on response styles: The number of response categories and response category labels. International Journal of Research in Marketing 27, 3: 236-247.

Wilcox, C., S. Linzey \& T.G. Jelen 1991. Reluctant warriors: Premillennialism and politics in the moral majority. Journal for the Scientific Study of Religion 30, 3: 245-258.

Wilkinson, P. 2000. City profile: Cape Town. Cities 17, 3: 195-205.

Wilson, K.M. \& J.L. Huff 2001. Scaling satan. The Journal of Psychology 135, 3: 292-300.

Wright, N.T. 1992. The New Testament and the people of God. Minneapolis: Fortress Press.

Zinnbauer, B.J., K.I. Pargament, B. Cole, M.S. Rye, E.M. Butter, T.G. Belavich, K.M. Hipp, A.B. Scott \& J.L. Kadar 1997. Religion and spirituality: Unfuzzying the fuzzy. Journal for the Scientific Study of Religion 36, 4: 549-564.

Thomas J. Farrar Khanyisane A. Falake Adriel Mebaley Mandisi D. Moya Ivor I. Rudolph

Department of Mathematics and Physics Cape Peninsula University of Technology Correspondence: farrart@cput.ac.za 